\title{
Pengolahan Kopi Bubuk dan Pemasaran Berbasis Digital Marketing dalam Meningkatkan Daya Saing Hilirisasi Kopi di Kawasan Lereng Menoreh
}

\author{
Masrukan, Fahmi Rafika Perdana, Kristiana Sri Utami, SL. Harjanta \\ Universitas Widya Mataram, Yogyakarta, Indonesia \\ E-mail: mrukan@gmail.com
}

Info Artikel

Kata kunci:

Kopi Lemon, Pascapanen, technopreneurship

\begin{abstract}
Diversification of post-havesting of coffe managed by the coffee farming group in the Sidoharjo district, Kulonprogo has several problems in post-harvest handling and processing coffee, especially in processing of coffee powder with good manufacturing process (gmp) as well as conventional marketing management. Through the Community Partnership Program (PKM), the service team provide solutions to outcome problems through several methods; 1) training and assistance in postharvest handling 2) training and assistance in the production of ground coffee in a natural process and 3) training and assistance in marketing management with digital marketing. The results of the assistance are the post-harvest handling and processing of coffee properly and correctly by producing ground coffee with the brand name "Lemon" as well as better managed marketing, not only in a conventional manner but also by using marketing based technologoy (www .kopilemon.com). With this Community Partnership Program, it has an impact on increasing the competitiveness and welfare of coffee farmers in the Menoreh area
\end{abstract}




\section{PENDAHULUAN}

Kecamatan Samigaluh adalah sebuah kecamatan di Kabupaten Kulonprogo, Provinsi Daerah Istimewa Yogyakarta, memiliki luas wilayah terbagi dalam tujuh wilayah desa, diantaranya adalah Desa Sidoharjo, daerah berbukit yang merupakan wilayah perbukitan Menoreh, mempunyai luas wilayah 1.374,46 ha (19,84\% dari total wilayah Kecamatan Samigaluh) ketinggian di atas 600 mdpl, sehingga kebanyakan penduduknya adalah petani. Sejak tahun 2012 usaha pemberdayaan masyarakat di wilayah Bukit Menoreh sebagai upaya meningkatkan perekonomian masyarakat terus diupayakan, salah satu bentuk pemberdayaan yang dilakukan adalah dengan memanfaatkan tanaman lokal seperti kopi untuk dikelola menjadi produk kopi dan turunanya,sebagai bentuk hilirasasi tanamankopi.Kopi merupakan komoditi perkebunan yang diunggulkan di wilayah perbukitan Menoreh. Varietas yang dikembangkan yaitu kopi robusta yang pengolahannya dilakukan secara organik oleh petani setempat. Kopi Menoreh tumbuh secara alami tanpa menggunakan pupuk kimia, mempunyai aroma yang khas yaitu aroma spicy, caramelly, flowery. Kopi robusta Menoreh dipanen dengan menggunakan tangan (secara manual), hanya biji kopi yang berwarna merah saja yang dipetik dan diproses menjadi green bean. Bertrand et al., (2012), menyimpulkan bahwa biji kopi spesial dapat diperoleh dari kopi yang ditanam pada iklim yang ideal yaitu pada ketinggian tempat yang lebih tinggi dimana kualitas sensorinya menunjukkan hasil yang lebihbaik.

Hilirisasi kopi di kawasan bukit Menoreh merupakan usaha mengolah buah kopi menjadi produk siap saji (kopi bubuk) yang memiliki prospek ekonomi yang baik. Sebagai perbandingan, harga perkg buah ceri kopi merah adalah Rp 8.000-10.000, sedangkan kopi bubuk perkg adalah Rp 50.000-60.000, sehingga perlu dilakukan manajemen usaha yang profesional dari penanganan pascapanen kopi, pengolahan kopi, dan bahkan sampai manajeman pemasaramya. Usaha hilirisasi kopi Menoreh ini sudah dilakukan dengan membentuk usaha kelompok tani yaitu "Kelompok Industri Tani Kopi Menoreh (KITKM)", dengan harapan kelompok tani tersebut bisa memperoleh kesejahteraan ekonomi dansosial.

Permasalahan yang timbul dalam proses hilirisasi produk kopi Kelompok Industri Tani Kopi Menoreh, di Desa Sidoharjo Samigaluh ini adalah penanganan pascapanen kopi,, pengolahan produk hilir kopi yang berupa kopi bubuk, dan manajamen pemasaran yang masih menggunakan metode konvensional. Pada penanganan pascapanen dan pengolahan kopi bubuk, buah kopi hanya disimpan di gudang tanpa ada sirkulasi yang memadai, sehingga menyebabkan adanya cemaran jamur aflatoksim maupun okratoksin pada kopi. Sedangan pada pengolahan kopi bubuk masih belum dilakukan secara baik dan benar, terkait dengan penerapan ilmu dan teknologi pangan (kopi) sehingga mutu dan kualitas produk yang dihasilkan masih belumoptimal. Permasalahan yang menjadi titik penting dari hilirisasi kopi di kawasan Lereng Menoreh adalah bagaimana mengupayakan hasil dari kopi bubuk bisa dikenal dan bisa dipasarkan dalam lingkup lokal, regional bahkan nasional.

Berdasarkan pengamatan tersebut, maka perlu dilakukan transfer ilmu pengetahuan dan teknologi untuk memperbaiki proses penanganan pascapanen buah kopi, pengolahan produk hilir kopi dengan baik dan benar dengan mengedapankan sanitasi produksi, serta peningkatan kualitas sumber daya manusia 
dalam memasarkan produk kopi dengan mengedepankan teknologi online (website dan media sosial). Dengan demikian hilirisasi produk kopi dan turunanya benarbenar dapat meningkatkan kesejahteraan ekonomi dan sosial bagi petani di kawasan Lereng Menoreh.

\section{METODE}

Kegiatan PKM ini dilaksanakan dengan melibatkan partisipasi aktif anggota kelompok tani kopi di kawasan Lereng Menoreh,sehingga mereka berperan sebagai subyek kegiatan. Al Theresia dkk, (2015) berpendapat, partisipasi menjadi bagian penting dalam pencapaian tujuan pengembangan masyarakat, demikian pun termasuk dalam meningkatkan daya saing masyarakat tani kopi dalam program pengabdian ini. Secara umum partisipasi dapat diartikan sebagai keikutsertaan seseorang atau kelompok anggota masyarakat dalam suatu kegiatan Keikutsertaan yang dimaksud dimulai dari pelibatan dalam identifikasi masalah, pengambilan keputusana, proses perencanaan kegiatan, proses pelaksanaan kegiatan, pemanfaatan hasil kegiatan dan evaluasi.

Adapun tahapan atau langkah-langkah pelaksanaan kegiatan yang telah dilakukanuntuk mencapai tujuan kegiatan pengabdian iniadalah sebagai berikut :

1. Pelatihan dan pendampingan penanganan pascapanen kopi dengan metode greenhouse

sebagai tempat pengeringan dan penyimpanan sementara. Pada tahap ini gudang penyimpanan diberikan sirkulisasi udara untuk mengatur tingkat kelembapan ruangan untuk mencegah timbulkan jamur pada kopi.

2. Pelatihan dan pendampingan pengolahan produk hilir kopi (kopi bubuk) dengan baik dan benar dengan memperhatikan prinsip sanitasi dan kaedah cara produksi makanan yang baik dan benar (CPMB).

3. Pada pelatihan manajemen pemasaran obyek pengabdian diberikan materi mengenai strategi pemasaran. Salah satu model pemasaran yang diberikan mengacu pada manajamen usaha berbasis teknologi.

4. Evaluasi dan tindak lanjut.

Pada tahapan akhir dilakukan evaluasi dari keseluruhan kegiatan yang bertujuan untuk mengetahui seberapa efektif dan bermanfaatnya program atau kontribusinya pada pihak yang menjadi sasaran. tindak lanjut kemudian sangat dibutuhkan untuk terjaminnya keberlangsungan pengembangan masyarakat petani kopi yang berdaya saing tinggi dan peningkatan kesejahteraan.Sedangkan alat-alat atau sarana prasarana yang digunakan untuk pelaksanaan kegiatan ini adalah camera recorder, laptop, screen proyektor, media komunikasi serta prasarana yang digunakalan dalam produksi kopi bubuk; huller, grinding, roasting, ayakan, plastik kemasan, sealer mechine.

\section{PEMBAHASAN}

\section{Hasil dan Pembahasan Kegiatan Program Kemitraan Masyarakat (PKM)}

\section{Sosialisasi Kegiatan Program Kemitraan Masyarakat}

Setelah merumuskan permasalahan dan penentuan prioritas penyelesaian permasalahan, kemudian kegiatan berlanjut pada sosialisasi program pada pihak- 
pihak terkait. Pihak-pihak terkait meliputi kelompok tani kopi di kawasan Lereng Menoreh, penyuluh pertanian, masyarakat sekitar (non kelompok tani) dan stakeholder pemerintahan. Pada tahap sosialisasi dilakukan gambaran terkait sanitasi dalam produksi, pembuatan konten profil kelompok tani, dan Sosialisasi terkait hilirisasi dari off farming sampai pemasaran. Selain itu juga disiapkan sarana prasarana terkait kegiatan penyuluhan dan pendampingan proses pengolahan kopi (Gambar 1 dan Gambar 2).

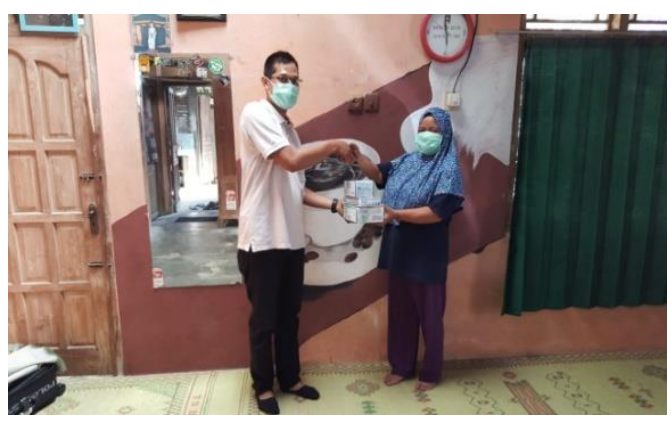

Gambar 1. Sosialisasi sanitasi produksi

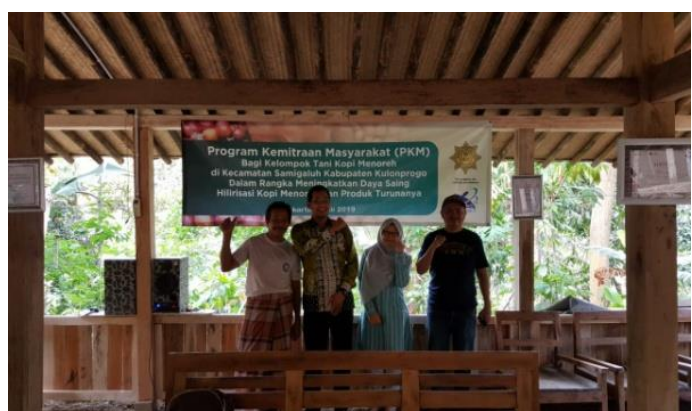

Gambar 2. Sosialisasi kegiatan PKM

\section{Pelatihan dan Pendampingan Penanganan Pascapanen Kopi dengan Metode}

\section{GreenHouse}

Teknologi pasca panen kopi mempunyai peranan penting dalam menjaga kualitas kopi tetap baik tanpa tercemar oleh jamur. Rusdianto (2008), terdapat dua titik kritis tahapan yang sangat berpotensimenyebabkan tumbuhnya kapang Aspergillusochraceus yang mampu menghasilkanokratoksin. Tahapan tersebut adalahpengeringan dan penyimpanan. Pada pendampingan ini diberikan konsep terkait penyimpanan kopi di galam gudang penyimpanan dengan memperhatikan suhu, sirkulasi udara dan kelembapan udara. Gudang penyimpanan pada kopi green dijaga pada suhu $20-27^{\circ} \mathrm{C}$ dengan tingkat kelembapan udara yang sedang sehingga biji kopi green tetap terjaga dengan baik (Gambar 3 dan 4). Metode yang digunakan adalah green house. Pastik ultra violet (UV) digunakan sebagai atap gudang penyimpanan. Kandungan bahan kimia umumnya UV protektor yang fungsinya untuk melindungi tanaman dari efek negatif sinar ultra violet pada sinar matahari. Semakin tinggi kandungan UV Protector maka warna plastiknya semakin buram. Untuk keperluan greenhouse umumnya memakai plastik UV kandungan 14\%, sedangkan untuk penjemuran atau pengeringan hasil panen memakai plastic UV yang kandungannya $6 \%$. 

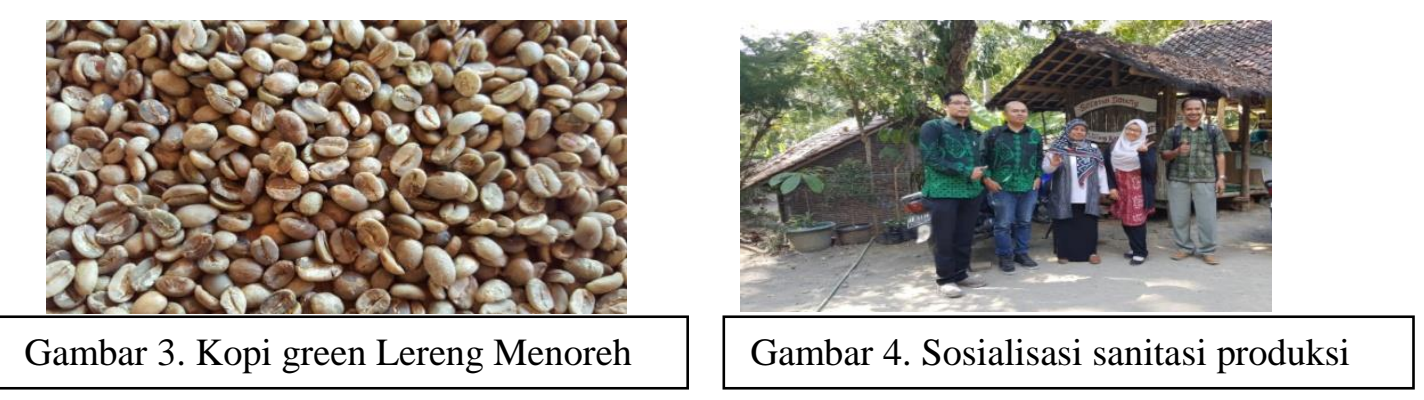

Selain menggunakan plasti UV, karung berpori (karung goni) juga digunakan sebagai wadah primer pada kopi green. Hal tersebut untuk menjaga sirkulasi udara pada kopi green dengan lingkungan sekitar tetap lancar dan tetap mempu terjaga kualitasnya sebelum kopi tersebut disangrai.

\section{Pelatihan dan pendampingan pengolahan kopi bubuk dengan cara baik dan benar}

Pada pelatihan dan pendampingan pengolahan kopi bubuk, tim pengabdi menekankan pentingnya sanitasi dalam proses pengolahan. Dalan pengajuan izin edar produk, sanitasi menjadi faktor utama dalam sebuah proses produksi. Proses pengolahan kopi bubuk yang diterapkan di kelompok tani menggunakan natural process atau cara kering (Gambar 5). Proses natural meliputi sortasi basah, pengeringan, pengupasan kulit (kulit tanduk dan ari), sortasi kering, penyangraian, dan penggilingan. Pada sortasi basah dilakukan untuk memilih buah ceri yang berwarna merah dan tidak cacat karena termakan serangga. Pengeringan dilakukan untuk mengurangi kadar air sampai kadar $12-13 \%$ serta fermentasi secara natural. Pada proses natural, buah kopi yang dikeringkan masih dalam berbentuk buah/ceri, lengkap dengan semua lapisan-lapisannya. Prosesnya yang natural dan alami ini akan membuat ceri terfermentasi secara natural pula karena kulit luar ceri akan terkelupas dengan sendirinya. Pengupasan kulit dilakukan dengan menggunakan mesin huller yang mampu memisahkan kulit ari dan kulit tanduk sehingga diperoleh green kopi. Selanjutnya dilakukan sortasi kering untuk memisahkan green kopi berdasarkan ukuran, dan kualitas (kotoran dan biji pecah).

Proses penyangraian adalah proses pembentukan rasa dan aroma pada biji kopi dan menjadi titik kritis pada pengolahan kopi bubuk. Biji kopi memiliki perbedaan ukuran dan densitas yang beragam, sehingga proses penyangraian merupakan seni dan memerlukan ketrampilan dan pengalaman sebagaimana permintaan konsumen. Proses penyangraian dilakukan dengan menggunakan suhu yang tinggi. Biji kopi disangrai pada suhu $150-200{ }^{\circ} \mathrm{C}$, suhu tersebut bisa berubah sesuai dengan level sangrai yang diingikan.

Selama proses penyangraian berlangsung, terjadi perpindahan panas dari permukaan pemanas ke dalam bahan. Panas yang masuk ke bahan menyebab kanperubahan suhu dalam bahan. Panas yang menyebabkan perubahan temperatur bahan tersebut dinamakan panas sensible. Kondisi ini akan berakhir ketika keadaan mulaijenuh yaitu bila suhu bahan terus meningkat sampai mendekati suhu penyangraian.Keadaan seperti ini diakibatkan adanya panas latent penguapan yang 
menyebabkan terjadinya perubahan massa (air) yang terkandung dalam bahan (Joko Nugroho, WK., dkk 2009). Selanjutnya adalah penggilingan kopi sangrai. Tujuan dari penggilingan ini adalah untuk mendapatkan ukuran bubuk dari kopi, pada umumnya ukuran kopi bubuk berkisar antara 40-80 mesh. Pemilihan Natural process pada pengolahan kopi bubuk ini dikarenakan terbatasnya sarana air untuk proses fermentasi, selain itu dengan cara tersebut aroma kopi yang terbentuk pada saat roasting memiliki aroma moka dan rasa buah (blueberry, strawberry atau buahbuahan tropis). Kopi pun cenderung memiliki keasaman (acidity) rendah, rasa-rasa yang eksotis dan body yang lebih banyak.
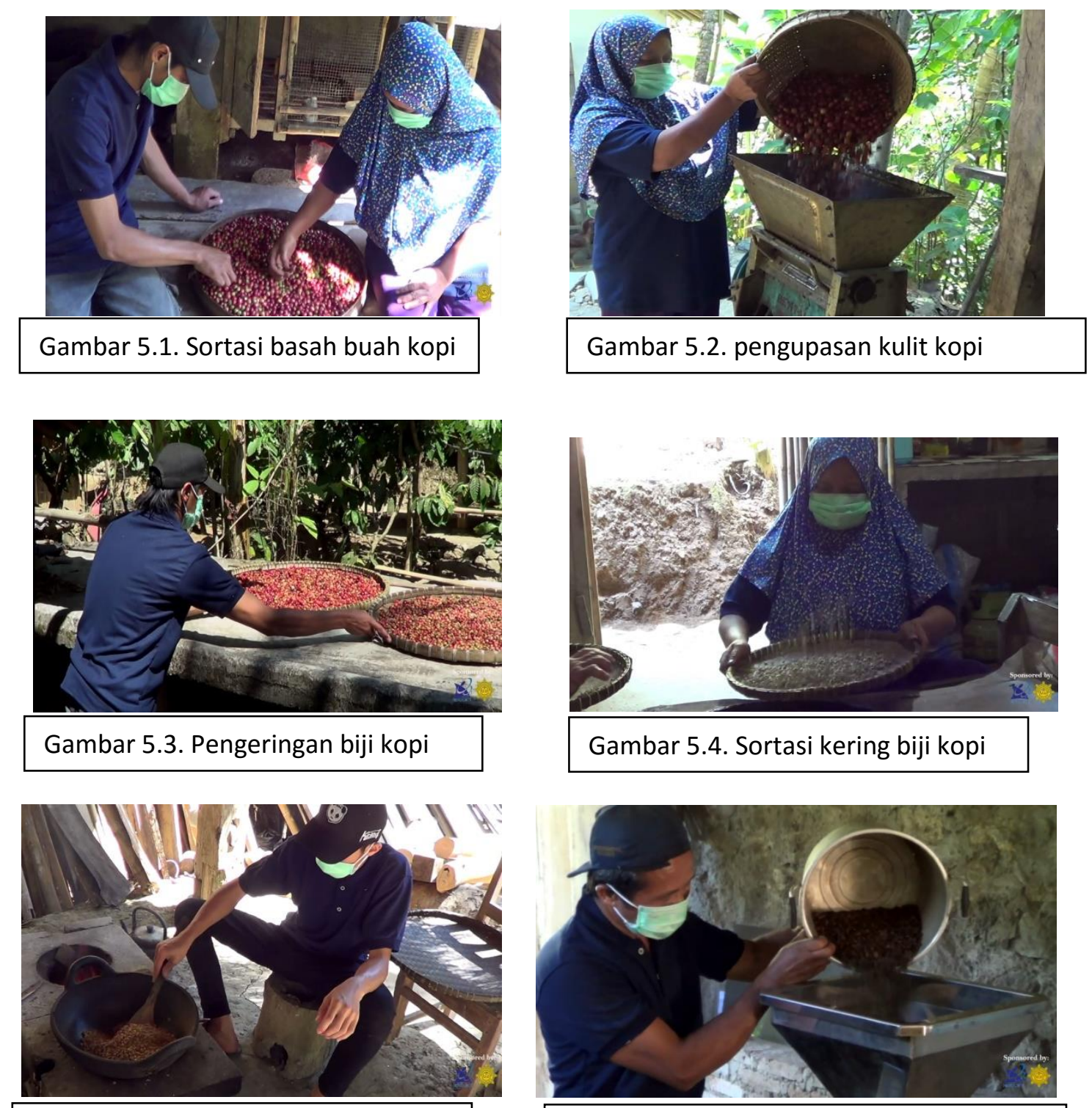

Gambar 5.5. Roasting biji kopi

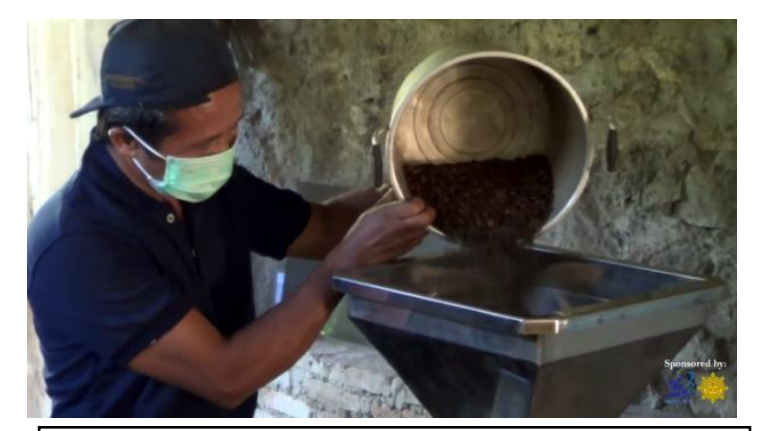

Gambar 5.6. penggilingan kopi sangrai 


\section{Pelatihan dan Pendampingan Manajemen Pemasaran dengan Digital Marketing.}

Pada tahap pendampingan pemasaran produk kopi Lereng Menoreh (Lemon), peserta kelompok tani diberikan informasi terkait usaha pemasaran menggunakan website, selain itu dalam upaya memberikan kesan promosi pada produk kopi lemon tersebut juga disampaikan terkait prosedur untuk mendapatkan legalitas izin produk pada Kopi Lemon meliputi Pangan Industri Rumah Tangga (PIRT) dan sertifikasi Halal. Pemasaran online memiliki beberapa penyebutan atau istilah lain. Diantaranya, digital marketing, pemasaran web dan pemasaran digital. Digital marketing dianggap efektif untuk diterapkan oleh UMKM dalma pemasaran produknya. Purwana et al. (2017) menyatakan lebih lanjut bawah digital marketing adalah kegiatan promosi dan pencarian pasar melalui media digital secara online dengan memanfaatkan berbagi sarana misalnya jejaring sosial. Melalui website ini (www.kopilemon.com), para kelompok tani bisa memasarkan produknya secara langsung dan tanpa batasan apapun. Selain itu juga ditampilkan berbagai jenis kopi yang diproduksi kelompok tani tersebut, baik arabika maupun robusta. Sehingg konsumen juga bisa mengetahui apakah jenis kopi yang diinginkan readystock atau tidak. Ini memudahkan bagi konsumen untuk memilih jenis kopi lain yang stoknya ada. Kemudahan ini tentu tidak bisa dinikmati jika sistem pemasarannya dilakukan secara tradisional.

Tak hanya bisa mem-branding, produk-produk olahan kopi, dalam website tersebut juga ada layanan pemesanan langsung. Melalui layanan chat whatsapp, calon pembeli bisa melakukan transaksi atau pemesanan secara online. Layanan tersebut juga bisa digunakan konsumen untuk bertanya maupun mencari informasi seputar produk olahan kopi lereng Menoreh. Kerap kali, konsumen menginginkan informasi yang sifatnya detail dengan cepat dan mudah. Chat whatsapp ini sangat membantu bagi konsumen yang membutuhkan informasi yang mungkin tidak tersedia di dalam website. Hal ini juga sesuai dengan pendapat Carniels et al. 2014 yang menjelaskan penggunaan internet oleh kelompok tani memudahkan pertukaran informasi secara instan merangsang efisiensi dan membantu memecahkan masalah sejak tahap awal. Keberadan digital marketing ini akan membuat lebih efisien bagi petani dalam menjual produknya. Dengan begitu, digital marketing ini mampu meningkatkan daya saing kopi menoreh dibandingkan dengan menggunakan pemasaran secara tradisional. Melalui website ini, Kopi Lereng Menoreh juga makin memiliki posisi tinggi dibanding kopi-kopi yang berasal dari wilayah Indonesia yang lain.

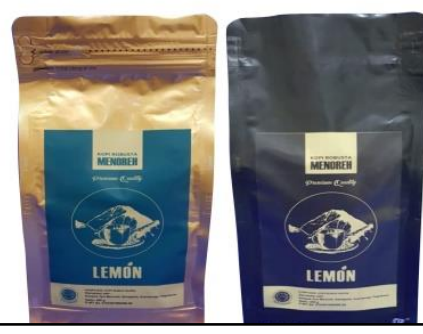

Gambar 6. Produk kopi bubuk

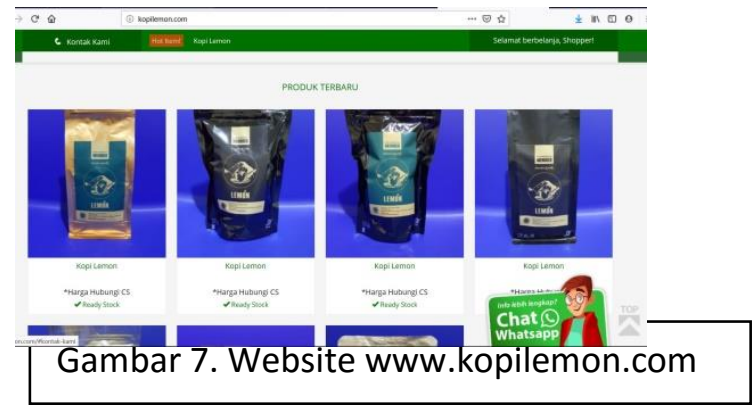




\section{Evaluasi Program.}

Pada tahap evaluasi program dan tindak lanjut ini diperlukan pengembangan proses pengolahan kopi bubuk, tidak hanya dengan menggunakan proses kering, tetapi juga menggunakan proses basah (washed process) dan honey process sehingga akan didapatkan aroma (flavour) yang lebih beragam.

Pada sistem pemasaran, diperlukan kerjasama dengan stakeholder terkait perumusan desawisata untuk mewadahi potensi lokal dari produk-produk disekita Lereng Menoreh sehingga kopi Lemon ataupun produk unggulan setempat mudah dikenal oleh masyarakat. Selain itu juga diperlukan pendampingan dan pelatihan untuk mengelola website menjadi lebih menarik dan komunikatif, sehingga website www. kopilemon.com dapat bertahan dan berkembang untuk memasarkan produk kopi kopi dan produk unggulan setempat. Pelaksanaan kegiatan ini mendapat respon yang baik dari tokoh masyarakat, pemuda, stakeholder pemerintahan dan para kelompok tani di sekitar Lereng Menoreh. Respon positif dari masyarakat terbukti dengan kehadiran masyarakat mengikuti kegiatan pengabdian masyarakat, dari $100 \%$ undangan yang disebar luaskan ada 60 sampai dengan $70 \%$ masyarakat yang menghadiri kegiatan tersebut.

\section{PENUTUP}

Melalui kegiatan PKM pada masyarakat petani Kopi Menoreh di Kelurahan Sidoharjo, Kecamatan Samigaluh, Kabupaten Kulonprogo telah mampu meningkatkan kemampuan para petani dalam penanganan pascapanen buah kopi dan pengolahan buah kopi bubuk. Kopi bubuk dengan brand Lemon telah berhasil depasarkan melalui website www.kopilemon.com. Dengan adanya website tersebut kopi bubuk dari olahan kelompok tani di sekitar Lereng Menoreh akan lebih mudah dikenal dan dipasarkan langsung baik tingkat lokal, regional dan nasional sehingga daya saing dan kesejahteraan kelompok tani di sekitar lereng menoreh bisa semakin meningkat.

\section{REFERENCES}

Bertrand, B., Boulanger, R., Dussert, S., Ribeyre, F., Berthiot, L., Descroix, F., and Joet, T. (2012). Climatic factors directly impact the volatile organic compound fingerprint in green arabica coffee bean as well as coffee beverage quality. Food Chemistr., 135: 2572-2583.

Caniels MCJ, Heidi KLL, Cees JG. 2014. Explainning the Internet Usage of SMEs : The Impack of Market Orientation, Behavioural Norms, Motivation and Technology Acceptance. Emerald Group Publishing. 25(3) : 358-377

Nugroho, Joko. WK, Lumbanbatu, Juliaty,\& Rahayoe. S.(2009), Pengaruh Suhu Dan Lama Penyangraian Terhadap Sifat Fisik-Mekanis Biji Kopi Robusta, Prosiding, ISSN 2081 - 7152.

Purwana, et al. 2017. Pemanfaatan Digital Marketing Bagi Usaha Mikro, Kecil, dan Menengah (UMKM) di Kelurahan Malaka Sari, Duren Sawit, dalam Jurnal Pemberdayaan Masyarakat Madani (JPMM) Volume 1 Nomor 1. 
Rusdianto AS. 2008. Peningkatan Kualitas Kopi Rakyat Dengan Penerapan HACCP. Jember

http://.plastikuvgreenhouse.com/perlakuan-pascapanen-pada-kopi-menggunakanplastik-uv- ultra-violet/, diakses tanggal 23 Desember 2016. 